\title{
Biodegradation of pesticide complex chlorpyrifos + cypermethrin by microorganisms isolated from the Southern Aral Sea region
}

\begin{abstract}
Microbiological study of soil samples with low pesticide content was conducted. Seven pure cultures were isolated: four related to Bacillus and three to Pseudomonas genera. Conducted study analyzing growth and biochemical activity of natural cultures on synthetic media revealed ability of two cultures (Bacillus sp. 2 -30 and Bacillus sp. $1-17)$ to degrade complex of pesticides chlorpyrifos+cypermethrin.
\end{abstract}

Keywords: selective transfer, superficial layer, structural analysis, intensity x-rays, width of diffraction lines, crystalline network constant
Volume 3 Issue 3 - 2018

\section{Tashpulatov JJ, Zaynitdinova LI, Juraeva RN, Lobanova IV, Kukanova SI \\ Institute Microbiology of the Uzbek Academy of Sciences, Uzbekistan}

Correspondence: Zaynitdinova LI, Institute Microbiology of the Uzbek Academy of Sciences, Tashkent, Uzbekistan, Email kukanova_s@mail.ru

Received: April 03, 2018 | Published: June 26, 2018

\section{Introduction}

Anthropogenic natural disaster of the Aral Sea and decreasing outflow of rivers Amudarya and Syrdarya caused a number of irreversible changes in soil microbial communities in the Southern Aral Sea region. Common features of these soils is their high salinization, extreme instability of humidity level up to total draught, and high content of different xenobiotics. ${ }^{1,2}$ Soil borne microorganisms are one of the main factors controlling degradation of xenobiotics in the natural ecosystem and essential bioindicators reflecting changes in soil, which is related to their enormous importance in soil formatting processes. There is possibility of emergence of strains in microbial populations of such soils that are capable to active degradation of pesticides. ${ }^{3,4}$ Such cultures, undoubtedly, are perspective for rehabilitation of natural environments. ${ }^{5}$ The approach engaging microorganismsbiodestructors for rehabilitation of soils polluted with agrochemicals has certain efficiency and effectiveness. Indigenous strains of soil borne microorganisms possessing both ability to destroy pesticides and natural resistance to the complex of pollutants and sharp changes of climatic conditions stipulate importance and feasibility of this approach. In these regards, the microbial biota of the Southern Aral Sea region, characterized by extreme natural conditions, was studied. Different microorganisms were isolated and their ability to destroy pesticides was determined.

\section{Materials and methods}

Soil samples with low pesticides content were used as an object of study. A mixture of pesticides chlorpyrifos+cypermethrin was used for determination of pesticides degradation degree by microorganisms. Number of microorganisms in $1 \mathrm{~g}(1 \mathrm{ml})$ of substrate was determined by the method of serial dilutions with cultivation of solid and liquid nutrient media. ${ }^{6}$ Preliminary identification of bacteria was conducted according to Bergey's manual. ${ }^{7}$ Protein was determined according to Lowry. ${ }^{8}$ Study of pesticides degradation was conducted on synthetic liquid nutrient medium M9 with addition of pesticides mixture, final concentration of which was 50/5 g/l chlorpyrifos/cypermethrin. Determination of pesticides in samples was conducted by gasliquid chromatography in the chemical lab of the Center of Hydro meteorological Service at Cabinet of Ministers of the Republic of Uzbekistan.

\section{Results and discussion}

Results of conducted study revealed that in salinized soils with residual concentrations of pesticides determined quantity of sporogenous, ammonifying and oligonitrifying microorganisms considerably decreases, denitrifying bacteria and Actynomycetes are practically not isolated. The total number of bacteria isolated on beef extract peptone agar (BPA) is relatively considerable for such soils (Table 1). Bacterial biota is represented both by nonsporogenous bacteria from genus Pseudomonas and by bacillary forms of microorganisms. Presence of sporogenous microorganisms practically in all studied samples should be noted separately.

Table I Microbiological analysis of soils with residual concentrations of pesticides

\begin{tabular}{|c|c|c|c|c|c|c|}
\hline \multirow[t]{2}{*}{ Soil sample } & \multicolumn{6}{|c|}{ Number of microorganisms, CFU/g } \\
\hline & BEA & Ammonifying & Sporogenous & Oligonitrifying & Denitrifying & Azotobacter \\
\hline 1 & $7.5 \times 105$ & $2.0 \times 103$ & $3.4 \times 102$ & $3 \times 102$ & $2.5 \times 102$ & Single cells \\
\hline 2 & $3.8 \times 101$ & $6.0 \times 102$ & $2.5 \times 10$ & $2.8 \times 102$ & - & - \\
\hline 3 & $5.0 \times 105$ & $6.0 \times 102$ & $2.1 \times 102$ & $5.6 \times 102$ & - & Single cells \\
\hline 4 & $3.3 \times 105$ & $2.5 \times 103$ & $6.0 \times 102$ & $1.8 \times 103$ & - & - \\
\hline 5 & $2.6 \times 105$ & $6.0 \times 103$ & $1.8 \times 102$ & $3.6 \times 102$ & $6.0 \times 101$ & - \\
\hline
\end{tabular}


Out of studied soil samples the most often isolated species of bacteria were selected and received in pure cultures (multiple passages and analysis of growth of corresponding nutrient medium). As result, seven pure bacterial cultures were received. On basis of conducted study of morphological and cultural and physiological and biochemical features four of them were identified as Bacillus and three as Pseudomonas species. Despite of many literature sources, data on pesticides' impact on soil borne microorganisms often contradictory. Different variations of suppression, activation and indifferent relation towards chemicals are determined among potentially possible reactions of soil borne microorganisms to pesticides' presence in environment and in processes involving their participation. In these regards, experiments on impact of pesticides on growth and vital functions of microorganisms participating in their degradation were conducted. Analysis of growth and biochemical activity of sporogenous cultures at cultivation on synthetic medium revealed univocal activity in several times exceeding control indices, which testifies digestion of pesticides as the only source of energy. Besides, considering indices on protein synthesis, it is necessary to note increased protein content on $7^{\text {th }}$ day of cultivation on synthetic medium, while maximal indices of protein biosynthesis are observed on $14^{\text {th }}$ day (Figure 1). Therefore, such indices of biochemical activity testify ability of bacilli cultures to use pesticides as a source of nutrition. Conducted chemical analysis confirms suggested propositions. Degradation of pesticides for strain Bacillus sp. 2-30 reached 93.4\%, whereas strain Bacillus sp. 1-17 degraded mixture of pesticides to $97 \%$ by $14^{\text {th }}$ day.

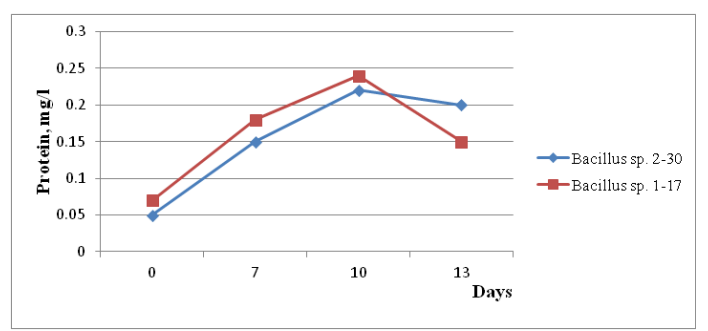

Figure I Dynamics of protein production by bacilli microorganisms on synthetic medium.

\section{Conclusion}

As result of the conducted research, different bacterial cultures were isolated from mixed populations of soil biota exposed to long-term impact of anthropogenic and natural factors. Obtained results allow to conclude that microbiota of studied soils is diverse. Detailed analysis of microbial diversity reveals that organizing role in microbiocenoses belongs to bacteria from Bacillus and Pseudomonas genera. Study of growth and biochemical activity of natural cultures cultivated on synthetic media determined possibility of strains Bacillus sp. 2 -30 and Bacillus sp. $1-17$ to degradation of pesticide complex.

\section{Acknowledgements}

None.

\section{Conflict of interest}

None.

\section{References}

1. Kurbanov AB. Hygienic evaluation of pesticides applied in the Republic of Karakalpakstan. Bilim. 2002.

2. Bazarbaeva DN, Kurbanov AB, Mustafina AZ. Pollution of environmental objects and their migration upon food chain in Karakalpakstan. Archives of the Karakalpak branch of the Academy of Sciences of the Republic of Uzbekistan. 2004;(5-6):19-22.

3. Kim KD, Ahn JH, Kim T, et al. Genetic and phenotypic diversity of fenitrothion-degrading bacteria isolated from soils. J Microbiol Biotechnol. 2009;19(2):113-120.

4. Cabrera JA, Kurtz A, Sikora RA, et al. Isolation and characterization of fenamiphos degrading bacteria. Biodegradation. 2010;21:1017-1027.

5. Diez MC. Biological aspects involved in the degradation of organic pollutants. J soil sci plant nutr. 2010;10(3):244-267.

6. Netrusov AI. Praktikum po mikrobiologii. Moskva: Akademija; 2005.

7. Kersters K, Vancanneyt M. Bergey's manual of systematic bacteriology. New York, Verlag: Springer; 2005.

8. Kresge N, Simoni RD, Hill RL. The most highly cited paper in publishing history: Protein determination by Oliver H. Lowry. Journal of Biological Chemistry. 2005;280(28):25. 